\title{
Thyroid Cancer pN1a TNM Finding v6 and v7
}

National Cancer Institute

\section{Source}

National Cancer Institute. Thyroid Cancer pN1a TNM Finding v6 and v7. NCI Thesaurus.

Code C60874.

Thyroid cancer with metastasis to pretracheal, paratracheal or prelaryngeal/Delphian lymph nodes (Level VI lymph nodes). (from AJCC 6th and 7th Eds.) 